\title{
Culture and History in the Halfway House: Ethnography, Tradition, and the Rural Middle Class in the West of Ireland
}

\author{
A. JAMIE SARIS
}

\begin{abstract}
In this essay, I examine aspects of the life of a mental hospital nurse in the context of two main discourses (1) cultural debates about Ireland over the course of the last century or so, and (2) how the west of the island has been portrayed in some ethnographic writings. I argue that this nurse is situated partially in and partially out of both these discourses, and, furthermore, he is implicated in reproducing some ideas that render such judgment possible. I put forward a concept of "brokerage" to explain how objects and narratives that invoke a "tradition" stretching back into contested and intellectually murky histories can be experienced as felt orientations within a cultural environment.
\end{abstract}

$* * * *$

What the battleaxe of the Dane, the sword of the Norman, the wile of the Saxon were unable to perform, we have accomplished ourselves. We have at last broken the continuity of Irish life, and just at the moment when the Celtic race is presumably about to largely recover possession of its own country - Douglas Hyde, The Necessity For DeAnglicising Ireland (1894).

\section{A Respectable Irishman}

"My father respected only two professions," mused Joe O'Brien in the dim afternoon gloom of MacDonagh's pub, "nursin' and police work. I was influenced by that." Joe is an older man, a mental hospital nurse with nearly thirty-five years of service, who, at the end of this research in 1995 was in the process of retiring. He hails from a small farm about six miles south and a bit west of Kilronan[a pseudonym], a market town whose history and current social existence alongside that of the mental hospital in which he works I have explored in previous studies (Saris 1994, 1996, 1997, 1999). Joe is the seventh of twelve children, the fifth boy, who remembers the days of "compulsory emigration" (speaking of economic conditions as if they had been legislated by the Dáil), when a noninheriting country lad, not bound for the priesthood or an apprenticeship in a town shop, was "for the road." This road generally led across the water. In another conversation, Joe remembered with regret a friend of his who took that road in the early fifties, only to bleed his life away on an unknown mountain top on the Korean peninsula during the course of an obscure war in an attempt to satisfy his new country as to his patriotism. "Nursin'," Joe 
continued soberly, "was one of the few professions where employment could be had. It kept me home."

I started to think seriously about Joe's life one day while waiting for tea in his living room. In this room, there is a rough oaken book case, the handiwork of Joe's father, Patrick O'Brien, when he was a young man. On these well-made, unfinished shelves, rests a veritable trove of old volumes, purchased for the most part by Patrick's father (also named Patrick). Amongst these works are Lady Gregory's English translation of the Cuchulain cycle, a third edition of Cuchulain of Muirthemne, and her translations of a variety of old Irish mythic sources that she published under the title, Gods and Fighting Men. There is also a much-prized early edition of Standish O'Grady's large work History of Ireland (from the late 1870s) that forms the scholarly basis of much of this historical/mythical material, as well as a first edition of Eleanor Hull's Cuchulain, The Hound of Ulster, a popularized version of the hero story for younger (male) readers published in 1909. Some of these works have been read, at least in part, by members of the family for three generations (four, including Joe's own children).

There exists, of course, an immense body of work on the literary roots of modern Irish nationalism, and its role in shaping current Irish sensibilities. Indeed, even a cursory summary of this material would require an essay of its own (see Popot 1979, Cairns and Davis 1988, Foster 1987, Lyons 1979, 1983, Williams 1983, Thompson 1967, Brown 1985, Eagleton, Jameson, and Said 1989, Saris n.d., among many others). In general, though, these writers share a similar narrative structure in their outline of events. They point to the "recovery" of a national literature starting in the mid-nineteenth century, leading to a literary "revival" in the last decade or so of the nineteenth century and the first two decades of the twentieth. This revival was a heady time, inspiring a burst of creativity across a wide variety of artistic fields. Finally, these works point to a waning of this artistic (and largely optimistic) impulse in the wake of political independence for Ireland in the 1920s with the advent of a small-minded, petit-bourgeois, excessively religious, political entity in the south of the island (Fitzpatrick 1977, Sheehy 1968, MacDonagh 1984), and the development of a sectarian rump state in Northern Ireland (see Brown 1985 for overview of this failure). Some of this literature, "recovered" in the nineteenth century, which apparently failed in its promise, if not in its seed, we find in the late twentieth century resting on Joe's shelves.

\section{In Between}

In this essay, I argue that Joe represents a stratum that is downplayed by different literatures about Ireland for different, but 
mutually enlightening, reasons. Current work on the near decadelong economic boom, the so-called Celtic Tiger, for example, tends to lump this rural middle class as part of traditional Ireland - they are considered to be more or less anti-modern, possessing attitudes and lifestyles have been constituted as both a drag on economic and social development and something of an embarrassment for the cosmopolitan sophistication of Dublin (O'Toole 1996, 1998, Sweeney 1998, among others). On the other hand, Joe's social position in rural Ireland (similar in many ways to that of Gards (police) and, to a lesser extent, teachers and lower level state employees) is also generally given short shrift in an Anglo-American tradition of ethnographic writing on life in the west of the island, basically because Joe O' Brien seems to be too historically transformative to be unproblematically part of "traditional" Ireland.

Mr. O'Brien is a farmer of about twenty acres of marginal land. He is the son of a small farmer, deeply involved with the concerns of rural life. He regularly attends Sunday Mass, and he is a presence in political organizing in his area. (According to family history, Joe's father, Patrick, fought on the anti-Treaty side in the Irish Civil War, and Joe, like his area, is strongly Fianna Fáil.) His wife, Mary, is active in the Irish Countrywoman's Association (ICA), an organization dedicated to preserving traditional crafts in rural Ireland. In short, by nearly any measure that the outside observer can come up with, Joe O'Brien is a "real local" (as opposed to a "stranger" or a "blow-in") and an important part of his "community" (all local words).

At the same time, Joe is also the dedicated employee of an originally British colonial institution, a large mental hospital, initially established as part of a broad wave of measures intended to discipline the Irish body and landscape towards recognizably civil (read "British") lines (Inglis 1991, Saris 1996, 1997, 1999). His sensibilities, while clearly rural and traditional in many respects, are also undeniably middle class, as everything from his modern bungalow to his local reputation as a "progressive" (i.e., marketoriented) farmer makes clear. At this level, we can read yet another instance of the influence of the mental hospital on local society (Saris 1994, 1996, 1997). In Joe's life history, for example, this influence has been the difference between a respectable local existence and an uncertain life as an emigrant. By the same token, due to the presence of this historically innovative institution, the "community" has gained a local pillar, a competent farmer and a successful political organizer.

Joe O'Brien - more or less devoutly Catholic, middle class and English-speaking - gives us the opportunity to think through such diverse problems as some theoretical issues in anthropology to 
heated cultural-political debates within Ireland concerning what is to be the relationship of the island to her various pasts and possible futures. These themes also relate to aspects of European ethnography in general and Irish ethnography in particular - that is, how narratives that invoke a "tradition" stretching back into contested and intellectually murky histories can be experienced as felt orientations within a cultural environment (Fernandez 1985, Popot 1979, Rafroidi 1983, Hertzfeld 1982, 1987, Handler 1986, 1988, Linke 1990, Bendix 1992, 1997, among many others). In Ireland, such themes are developing a certain urgency once again during the current economic boom, the so-called Celtic Tiger, as a variety of Irish commentators worry that "the Irish" are losing something authentic in the face of supposedly recent transformations, even as the appeal of Ireland as a prime destination for the cultural tourism market has never been higher (e.g., Wilson 1993, Waters 1998, among others).

\section{Peering at Ireland through Celtic Mists}

Those writing about the recent "modernization" of Irish society are fond of before-and-after binaries. For many critics, a crucial moment in the "before" epoch (e.g., Brown 1984, Lee 1989, and Foster 1989, among others) is a radio broadcast made in the country while Europe was at war with itself. In 1943, Eamonn de Valera (a personal hero of Joe O'Brien), the Prime Minister of the recently declared Irish Republic (1939) addressed the nation on St. Patrick's day. The mood was serious in the new state. For the past four years the country had been in the grip of The Emergency, endeavoring to maintain a precarious neutrality between the combatants in WWII, and for most of the previous decade had been engaged in an economic war with her main trading partner, and recent colonial master, Great Britain. While the war in Europe no longer threatened to spill over the island in the form of an outright invasion by Allied or Axis powers, the future of the Irish Republic was still cloudy.

In the midst of those uncertain times, De Valera, the only male leader of the 1916 Easter Rising ${ }^{1}$ to survive the British firing squads, asked his audience to reflect upon the principles which, he claimed, had called an independent Ireland into being twenty-five years earlier.

The Ireland which we dreamed of would be the home of a people who valued material wealth only as the basis of right living, of a people who were satisfied with frugal comfort and devoted their leisure to things of the spirit; a land whose countryside would be bright with cosy homesteads, whose fields and villages would be joyous with the sounds of industry, the romping of sturdy children, the contests of athletic youths, the laughter of comely maidens; whose firesides would be the forums of the wisdom of serene old men. [Irish Press 1943:1] 
This speech summons up a vista of Ireland which can still to be glimpsed in some Bord Fáilte ${ }^{2}$ brochures, i.e., a country composed of rural hamlets that are quaint, hardworking, and pious. The dominant image in this picture of Ireland is a particular sort of community. This community is necessarily rural, respectably poor, spiritual, and harmonious. It deliberately strikes one as spatially and temporally removed from the modern world (for other de Valera speeches, see Moynihan 1980). In present-day Ireland, the St. Patrick's day address has been seized on by many commentators as the veritable nadir of an economically backward, culturally inwardlooking, religiously and socially conservative state, out of which a modern society in Ireland is finally emerging.

Whatever we might think of it now, however, it is clear that De Valera's musings have roots in the intellectual and political debates around Irish national sensibilities that emerged towards the end of the nineteenth century, the same time as some of the earlier publications on Joe O'Brien's book shelf. In 1894, for example, Charles Gavan Duffy answered his rhetorical question, "What do we hope to make of Ireland?" with high praise for Switzerland and Belgium, countries that, to his eye, contained a people "not needing or desiring great wealth, but enjoying free, simple lives," in opposition to "the stricken legions who serve the steam engine and the water wheel" [a thinly veiled reference to England] (Duffy 1894:19-20). In 1903, the Rev. Thomas Macken addressing the conservative Maynooth Union echoed a common sentiment about the dangers that certain forms of modernization represented to an authentic Ireland, "No lover of Ireland - no genuine Irishman - can contemplate, without feelings akin to horror, an industrial Ireland with centres of manufacture such as are to be found in ... England" [emphasis mine] (cited in Cairns and Richard 1988:93-4). The De Valera speech mobilizes a set of images well established by the end of the nineteenth century concerning the distinguishing features of an Irish nation. These standards are a combination of a valorization of a rural-based economy, with limited industrial development and nonmaterialist, generally anti-cosmopolitan sentiments. This ideal Ireland would keep one eye on a glorious past (kept alive by the serene wisdom of old men) and one eye on a cosy future of nonconsumerist contentment (entrusted to the athletic youths and comely maidens). All these "standards" were established against a particular vision of England whose institutions, literature, and manufactures, it was argued, were inexorably swamping an authentic Ireland that was in danger of disappearing. 


\section{Cosmopolitan Nationalists and Traditional Innovators}

Life in this case does not imitate art. The St. Patrick's Day Address was delivered by an Irishman of Spanish-Cuban extraction. He was a devout Catholic, who was quite possibly born illegitimate. He ended up a respected statesman representing a small nation in the minefield of mid-twentieth century European diplomacy, who, in the crucible of civil strife, laid the basis of a political party that to this day still commands one of the most reliable pluralities in Western Europe (well over 40\%). In short, De Valera is not nearly as insulated from history as the remote community of his vision. He spent some of his childhood in the United States (indeed, it was his citizenship that saved him from the firing squads in 1916), and was educated as a teacher to staff the colonial school system. Rejecting this staid career, he become a revolutionary, and later, a faction leader in a bitter Civil War, and finally, an international statesman. Throughout this period, he also developed into an exceptionally skilled politician who bound together a coalition of nationalists, farmers, small town bourgeoisie, and the Church. This coalition survived more or less intact into the 1980s (Coogan 1993), and seems set to continue into the next millennium.

Despite such success, nearly all modern Irish historiography and cultural criticism is critical of De Valera's vision of Ireland (Brown 1981, Lee 1989, MacDonagh 1983, Cairns and Richards 1988: chs. 6-7, O'Toole 1985, Higgins 1985, Foster 1989). Such assessments, however, assume that something like the St. Patrick's Day address, indeed practically any speech in De Valera's long career, is a simple affair, either a sly nod by a cynical politician to reactionary peasants, novel elites, and national ideologues or the delusions harbored by a fanatic or a fantasist. Instead, I want to examine De Valera's musings as a dense text in a complicated context, folding back this complexity into the historical existence of someone like Joe O'Brien.

Throughout his long political career, De Valera never ceased to play along a line (one of his own discursive elaboration) between the "traditional" and the "modern." His Ireland was at once isolated from history, a community similar to his vision in the St. Patrick's Day speech, and at the vanguard of the struggle for humanity's spiritual transformation (Moynihan 1980). We need to understand this virtuoso creation and movement around rhetorical boundaries in order to understand his political style, and why he might, even in memory, holds a special appeal to someone like Joe O'Brien when contemplating his relationship to "traditional Ireland."

Joe is a dedicated employee of an institution, much of whose official history has been tied up with altering and rationalizing the lifeways of the inhabitants and the landscapes of the various 
localities with which it has interacted (Saris 1996, 1997, 1999). Whatever the dictates of this history, however, Joe also takes the notion of being an Irishman very seriously. Indeed, he considers his activities in such diverse spheres as his politics, his religion, and the way he socializes to be the very stuff of "Irishness." Even Joe's memory of his father's singular respect for "nursin' and police work" as "respectable professions" for a country lad is bound up with this conflicted history and the ambiguous meanings it has generated. Patrick O'Brien who (according to family history) as a young man saw action in the War of Independence, and by such measure would have to be considered a Nationalist, bequeathed to his son a profound admiration for those two rural professions that Robert Peel, the arch-enemy of Irish nationalist aspirations in the nineteenth century, established on the island. As Chief-Secretary to the Lord-Lieutenant, then Home Secretary, Mr. Peel, whose interests in modalities of power was Foucaultian in scope, was instrumental in giving Ireland a mental hospital system in the early 1820s and a paramilitary police force, The Irish Constabulary, in the $1830 \mathrm{s.}^{3}$ He was also a keen sponsor of a variety of Coercion Bills to keep Ireland "loyal." Joe's profession and his area's historical memory of it, then, are a curious combination of "traditional" and "modern," "local" and "foreign."

Perhaps it is not surprising, then, that well before formal political Independence, many of the major figures associated with the cultural wing of the movement to sever or severely attenuate the relationship between Ireland and Great Britain had expressed serious reservations about how Irish men and women were living and thinking in Ireland at the end of the nineteenth century that even today read like salvos against the day-to-day life of Mr. O'Brien. W.B. Yeats, in his scathing poem "September 1913," for example, complains bitterly about a petit bourgeois, excessively religious mentality that he finds rampant throughout the country (Kiely 1989: 68). Similarly, in "The Galway Races," Yeats valorizes an enchanted world before "the merchant and the clerk breathed on the world with timid breath" (Kiely 1989:58), leaving little doubt on which side of this historical and moral divide that he found the then-current thinking of many of his countrymen.

Other writers were, if possible, more to the point. Padraig Pearse, a school teacher and the main leader of the Easter Rising, in "The Murder Machine," an argument brimming with both anger and keen insights into the nature of institutions like schools in a dominated country, explicitly identifies the educational system in Ireland with a machine that manufactures "Things," more precisely "Things that are for sale" (Pearse (1912) 1986:6). Throughout this essay, Pearse lays out both a vision of a spiritual nationalism as well as his 
opposition to a valorization of efficiency and a thoroughgoing secularism that he argues are being inculcated by the educational institutions of the bourgeois state at the demand of the commodity economy. This system, according to Pearse is not only anti-Irish, but anti-human.

Ironically, Pearse, like De Valera, had a decidedly cosmopolitan family background to his personal nativism. His father was an English stonemason who emigrated to Dublin and converted to Catholicism. This profession was much in demand in post-Famine Ireland largely thanks in part to the boom in new and/or expanded institutional construction, from asylums and poor houses to churches and schools, during this period. Those interested in both the politics of tradition and psychoanalysis, will find it telling, therefore, that, throughout his polemics, Pearse directs most of his wrath against those Irish men and women who identified themselves with the modern state apparatus, particularly those staffing its bureaucracy and institutions, alternately characterizing them as "traitors," "jailer-slaves," and "dead men." Their distorted consciousness, alloyed as it was to daily social life throughout much of Ireland, Pearse maintained, was as dangerous an enemy to the Ireland that he was in the process of imagining (in Anderson's (1991) sense) as was the British army. Such people, Pearse argued, inevitably mistook the physical-technical aspects of government and politics for the spiritual reality of the nation. By working on the former, they would necessarily destroy the latter, settling for "halfmeasures" (note the phrasing) because they were no longer capable of recognizing the non-material, and therefore overwhelmingly compelling claim of the nation for "spiritual, intellectual, and political independence” (Pearse (1912) 1986:73).

\section{The Perils of the Halfway House}

Douglas Hyde, folklorist, founding member of the Gaelic League, and first President of Ireland, was another well-known voice in the chorus of condemnation directed at Irish men and women who were predominantly English-speaking and more or less respectably middle class, or at least strove to be. In his lecture, "On the Necessity of De-Anglicising Ireland" (originally titled "On the Necessity of De-Anglicising the Irish Race"), he argues that the majority of Irish men and women that he finds in the country are caught in a logically and politically untenable position, betwixt and between two more "real" states. 
imitate them; how it continues to clamour for recognition as a distinct nationality, and at the same time throws away with both hands what would make it so. [Hyde 1986 (1892):154]

It is from this image of the half-way house, of course, that I draw the title of this paper. Its original meaning was that of an inn or resting place midway between two points in a journey. It takes on its institutional cast, that of a semi-supervised housing situation between a prison or asylum and "free productive citizenship" in the early twentieth century, although I regret that I have not been able to run down its first use in Ireland. Hyde uses the term to convey movement (that is Ireland as a nation going in the wrong direction), the impossibility of stopping where she is (because she is in fact nowhere at all), and, therefore, the urgent necessity of turning around.

Clearly, Hyde puts forward two related ideas in this lecture that develop out of European speculation on the nature of "peoplehood" that can be traced back at least as far as Herder (1803). The first of these is the reality of specific markers of uniqueness of a people, amongst which differences in language enjoy a pride of place. The other is a visceral fear of spiritual/ethnic miscegenation - that is, established types should not too quickly or too completely mix with one another. In such an imaginary, "cultural" imitation became both the most sincere form of flattery to the imitated and the most obvious badge of degradation to the imitator (compare to Mosse's (1985) discussion of homosexuality). That part of the nation most isolated from intercourse with foreigners was ipso facto the most native, hence, Hyde's valorization of the Western seaboard of the island and some of its more remote inland fastnesses where Milisean purity had maintained its Aryan splendour. Indeed, for Hyde, too much cultural copying ultimately eroded the claim to European status altogether and so he argues that collectively the Irish stood in danger of becoming the "Japanese of Western Europe, lost to the power of native initiative and alive only to second-hand assimilation" (Hyde 1986 (1892): 169). There is, of course, a gentle irony in the fact that the current economic boom in Ireland has borrowed its appellation from the (until recently) strongly growing economies of Asia.

Hyde's thinking rests on what might be called a metaphysic of permanence, on the one hand, and of exchange, on the other. The notion of permanence is nicely embodied in the metaphor of "halfway," that is a state betwixt and between, or on the way to, one or another "more real" or enduring status. The sense here is that such a state is by its very nature unstable, and in Hyde's case probably harmful, not only for the folks involved, but for the prior, and more authentic, endpoints of the continuum. There is also a 
sense of debasement involved in Hyde's thought, a sort of Gresham's Law of the authentic, where the more adulterated currency of semiauthentic, or even absent, national sentiment drives out the truer, inherently more valuable version. To make matters worse, the more adulterated was this claim of "The Irish Race" to nationhood, the more difficult it became to uphold it in the European market for such goods, which ostensibly required distinctiveness of language, of custom, and, implicitly as the idea took hold in the nineteenth century, of biological purity as well.

\section{Anthropology and Ireland}

It is worthwhile to review some disciplinary history at this point: there has been a confluence of interests between the spinners of national tales and some of those who develop ethnographic narratives, particularly in the west of Ireland. ${ }^{4}$ American anthropology came to Ireland in 1932, about 8 years after the last flames of the Civil War had died down to smoldering embers, a little more than a decade after the War of Independence had ended with the partitioning of the island, and 16 years after the failed Easter Rising. The Cosgrave government - austere and fiscally and socially conservative - had just experienced an electoral defeat that was to test whether the new nation-state was capable of transferring power in a relatively peaceful fashion. The victors of the 1932 election were a coalition of Fianna Fáil and the Irish Labour Party. The former were the dominant partners. Led by De Valera, the new government was about to launch policies that were to embroil it in an economic war with Britain, its primary trading partner, and was to see the state's very existence threatened by the convulsions that rent Europe in the 30 s and 40s.

The discipline descended on an obscure corner of County Clare, part of the historic province of Munster, but a poorer part, sharing many features with Connacht, the Western province of Ireland. Clare, specifically Luogh, was chosen for its seeming statistical typicality - neither rich nor poor, anglicized enough so that English could form the basis of research but Gaelic enough that the old tongue could still be heard. To all appearances, it was "dominated" by the small peasant proprietor who formed the numerical backbone of the nation, and it was therefore rife with metonymic possibilities for the country and the society as a whole (Arenberg and Kimball 1940:chs. 1-2). Indeed, in many ways, Luogh matched the Fianna Fáil ideal of what Ireland should looked like. Containing pious country people, who still occasionally used the old tongue, who were all but self-sufficient except for a penchant for tea and white bread, and who were seemingly only tenuously articulated to larger systems 
(read the market), the area seemed to present itself as an ideal window upon the lifeways of the most numerous residents of the new Free State.

Anthropology descended on this romantic countryside in the person of a young Conrad Arensberg and Solon Kimball, both Harvard-trained anthropologists and veterans of the Yankee City project of Lloyd Warner. While the initial project was conceived as an exhaustive analysis of this small part of Ireland (the team included, for example, archaeologists and physical anthropologists), the project is best remembered for two volumes, The Irish Countryman (1937) and Family and Community in Ireland (1940, reissued and expanded 1968). The authors of these volumes make much of the American incarnation of the new theoretical gospel of Functionalism, arguing that tracing in detail how the various parts of "society" cohered and mutually supported one another, such that the social system as a whole was reproduced over time, advanced the understanding of the discipline, and implicitly, allowed it to treat "complex" societies for the first time.

Arensberg's "insertion story" tellingly plays on these themes. To the quaint inhabitants of Luogh, the anthropologist is the surveyor of old customs, a description regrettably true of too many of Arensberg's older colleagues bogged down in the wreck of the obsolete paradigms of Evolutionism and Diffusionism. Unbeknownst to the gentlepeople of Luogh, however, the new anthropologist is not after their past, but their present. He is not after the development of the tools that they use, or even how they diffused into the area or when they were invented, but their place in their day-to-day lives. And, while he expresses polite interest in the origin of their "customs," he is much more concerned to demonstrate how these customs and practices hold together the society in a synchronic present, rather than tracing the series of historical contingencies that made them fellows. It is not so much that history did not matter (Arensberg, for example, generously acknowledged his debt to the Irish historians Eoin MacNeil and George O'Brien), but that reproduction in the face of history, and the centrality of local dynamics in spite of broader connections, is the theoretical scaffolding on which the analysis is erected.

When put in this way, it is apparent that the past-saturated vision of Ireland elaborated in the St. Patrick Day's Address and Arensberg and Kimball's functionalist analysis of "family and community," share some features in common. Both discourses construct their objects, communities, as relatively stable entities, housing farms or cottage industries, only incompletely connected to the market economy, and, therefore, able to hold on in the face of historical change, market penetration, and/or class conflicts. We can trace 
these shared expectations about the nature of the authentically Irish in the west of Ireland at least within a specific tradition of works in dialogue with Arenberg and Kimball's baseline study, representing such diverse disciplinary perspectives as the modified cultural ecology of Robin Fox (1978) and the Meadian vision of Nancy Scheper-Hughes (1982). ${ }^{5}$ The remove of "community" from historical transformation and internal heterogeneity reached something of an apotheosis in Hugh Brody's work, Inishkillane: Change and Decline in the West of Ireland (1973), where nearly any class conflict or historical change is constructed as foreign. In short, from these anthropological representations of Ireland, we get a similar sense of the authentically Irish, i.e. that the true Ireland is to be found in the interstices or at the margins of bureaucratic structures and historical transformation (for critique, see Gibbon 1973 and Peace 1989).

\section{The Politics of Proportions}

There are some interesting connections, therefore, in the sources that are reviewed above. The audience that Douglas Hyde is chastizing in "The Necessity for De-Anglicising Ireland" (1894), for example, is precisely those successful farmers, shopkeepers, Irish bureaucrats, and state employees who were English-speaking in their day-to-day life and, he argued, blandly modernizing in many of their sensibilities. Many of these people do not look very different from the more successful folks in Luogh: English-speaking, albeit over a palimpsest of Gaelic, in the modern world, but with the residue of something older. The former discourse negatively emphasizes the historically transformative quality of their existence, while the latter concentrates on the presumably conservative features of their social life as the object of the analysis. Both discourses agree to label only parts of this social existence "Irish" and leave the rest as an object of hostility or relative indifference.

Such partialness seems a leitmotif in modern Ireland. The cultural purists who were interested in such diverse projects as the respiritualizing of Ireland to the revival of Gaelic as a vernacular tongue, found vast swaths of Ireland very much like Kilronan after Independence. Families were quite willing to allow (even require) the national schools to teach the language, for example, and certain individuals even quoted the odd phrase in the old tongue. On the whole, however, most showed no eagerness to change their everyday (i.e., Hiberno-English) speech habits. Similarly, while the inhabitants of these small towns and their environs took their formal obligations to Catholicism seriously (indeed, too seriously for many of their critics, e.g., Sheehy 1968), they remained in much the 
same economistic frame of mind that disappointed their critics a generation before. Finally, like the cultural purists, committed Nationalists berated the complacency of those who had a national government for turning their back on their northern brethren who still chaffed under English oppression. Nonetheless, during the Civil War, the newly independent Free State with which these rural middle class strata generally identified accepted British help to put down the anti-Partition faction. ${ }^{6}$

The example of Gaelic as a vernacular tongue in modern Ireland shows some of these tensions, and their partial resolutions. It has been an ideal of the Irish state since its inception that all its citizens learn the language well enough to speak it, despite the fact that by Independence probably less than a third (perhaps less than a quarter) of Ireland used Gaelic as a first language. Joe is the result of a school system that was far more intent on the goal of "reviving" the language than is the one at present. Nonetheless, Joe only possesses a command of the language that is sometimes derisively dismissed by more fluent speakers as "school Irish," enough to pass his exams (barely), but not enough competence, or the opportunity to acquire it after formal schooling, to make the regular use of the language a likely prospect.

This situation of one of the two official national languages being only imperfectly mastered by the majority of the population has been the case since the inception of the Irish state. To meet this challenge, De Valera (among other Irish politicians) cultivated a deliberate and peculiar style of oratory, beginning speeches in Gaelic, but swiftly swinging into English, to summon up an Ireland, whose persuasive force in modern politics was to derive from a certain rhetorical appropriateness, rather than current social reality. To this day, this format of delivering a greeting in Irish along with the first few lines of a talk and moving quickly, nearly imperceptibly, into English is still a ubiquitous public speaking form for everything from political talks on the national stage to junior public speaking contests in Ireland. From one point of view, it is an elegant solution to the problem of a "national" language, only incompletely mastered by much of an audience, but whose affective and political loadings for much of Ireland is undeniable. Precisely through such techniques, few people have so effectively presented and represented Ireland to herself or to the wider world as De Valera.

\section{Consuming Traditions}

De Valera's virtuoso management of tensions, ambivalences, even contradictions, helps explain some of his popularity in the O'Brien household. Clearly, Joe and his family do not fit well either into a 
vision of an unchanging, internally undifferentiated Ireland, or, into a model of a historically "cold" Ireland, only recently "developed" under the aegis of international capital. Joe works as a paraprofessional in the state bureaucracy inherited from a colonial power. The O'Brien family lives in a modern bungalow filled with modern conveniences, and they are conscious of their class in a variety of ways, from Joe's preference in cards (bridge rather than poker) to Mary's labor in the Society of St. Vincent de Paul, a charitable organization run by the solidly middle class in Kilronan.

Even Joe's small farm activities are conducted around the fact of his wage labor, a distinction that is not lost on, but still not considered foreign to, his "community." A small farmer of my acquaintance put it succinctly when I asked him to give me some idea of the sort of people that he knew from his townland who worked in the asylum.

They would have been seen here as being very active farmers, very ambitious farmers. They would mix in the community through their farmin' activity, rather than their role as nurses. They would also have been seen as more interested in land than farmin', like.

Well, you see their economic situation was better than most of their neighbors because they had a stable job. They could engage in more progressive farmin' methods because they had the backup of a job, a salary ... Yeah, they were progressive farmers.

Notwithstanding this local recognition of economic difference and contra Brody (1973), we very often find nurses remembered as agents of historical change while still remaining undeniably "local." Nurses, for example, often appear in recollections of local history as the first in a particular townland to put up a slate roof or build a bungalow in the place of an older farm house. The genealogies that I collected from these families, moreover, often showed both multigenerational contact with employment opportunities, with family networks providing a local entry point to a limited set of coveted jobs, a preeminently "traditional" arrangement. Even traditional cultural organizations like the Gaelic Athletic Association (GAA) could become recruitment grounds for the institution (for summary of GAA, see Mandle 1983). Such hobbies demonstrated, in the wry words of another older nurse consultant, "That one was Irish in mind to the hiring committee."

Over time, moreover, nursing families also tended to be more socially mobile than their small farmer counterparts. This mobility can be traced in such diverse ways as the amount of land farmed, positions in political organizations, getting offspring into the professions of law or medicine, and what I can only call a general local sense that these sorts of families contained people to be 
reckoned with. As we have seen in the case of Joe and Mary O'Brien, such individuals can even be political and/or social organizers at their localities, prominent in local party structures, charitable organizations, and cultural heritage societies.

It is scarcely surprising, therefore, that among Irish historians, it is becoming a commonplace that the development of the modern Irish nation-state relied heavily upon a stratum of successful farmers and shop-keepers, centered for the most part in small market towns, whose non-inheriting children often staffed the state bureaucracy as teachers and police, and, we might add, nurses (Brown 1984, Lee 1989:74). ${ }^{7}$ After the Famine, similar individuals just off the land also formed the backbone of the newly burgeoning religious orders (Larkin 1983, Inglis 1991).

Nonetheless, intimately connected to this undeniable sense of local historical agency in the life and historical consciousness of the O'Brien family, is the fact that both Joe and Mary subscribe to, and contribute to reproducing, a fairly static vision of tradition in Ireland. This sense of "tradition" is clearly connected to many of the symbols that were formalized during the Gaelic Revival, and were in part propagated in rural Ireland in the twentieth century through such mediums as De Valera's speeches. If Joe is recognized as a transforming force at his locality, as the idea of the "progressive farmer" makes clear, then he is simultaneously implicated, through many of his activities, from his reading interests to his political efforts, in propagating a sense of "tradition" that renders this local judgment possible in the first place. Indeed, through such activities he also helps make possible the judgment of outsiders that he is at times only problematically "Irish." Today, it is in the cultural existence of folks like Joe O'Brien where Cuchulain and European Union price supports for agriculture coexist with one another more or less peacefully, if, at first glance jarringly.

\section{Symbolic Projects}

And so we return to Joe's bookshelf. The crucial point here is that the literary works to which we have alluded, and the ideals of tradition and community to which they have been connected, fed into a variety of symbolic projects simultaneously in Ireland over the course of the last 150 years. Originally Anglo-Irish Protestants, for example, embarked on this project of summoning back the spirits of Fionn and Cuchulain in order to develop an Irish identity in opposition to the Roman Catholic affiliation of the majority of the island (see Foster 1987). This project was self-consciously a text-totext exercise, the high culture of an ancient, highly educated elite was to become part of the cultural capital of a modern, highly 
educated elite. Cairns and Richards (1988) make the case that this attempt was part of an exercise in hegemony by certain Anglo-Irish elements to claim a leading role in a changing Irish society, after they realized that their historic position as landed gentry had been fatally damaged by the political successes of the Catholic majority.

By the end of the nineteenth century, the means of recovery of Irish tradition had broadened to include folklore: the speech of the Gaelic-speaking areas was converted to texts for broader consumption in both Gaelic and English (e.g., Flower 1945, O'Sullivan 1966, Yeats 1951). Meanwhile, some of the earlier work was simplified, translated, and widely marketed (e.g., Hull 1909). In the second half of the nineteenth century, of course, Ireland also experienced significant social change, that included the vigorous development of the colonial state (and the resistances that this development provoked), as well as, of course, the precipitous drop in population on the island due to Famine and emigration. By the time of the formal launching of cultural revival organisations like the Gaelic League in 1894, the raw material for any number of symbolic projects had become available. Such symbolic projects are not completely amenable to any cultural trajectory as Appurandai (1981) rightly warns us, but they are diverse and malleable enough to serve several, sometimes competing, undertakings simultaneously (e.g., Frykman and Löfgren 1990).

It is hardly surprising, therefore, that waves of Irish experts have bemoaned their loss of the direction of the "recovery" to which they felt their labours had contributed. First, the heroes summoned back from historical obscurity had different ideas from those of the Ascendancy thinkers who called them into the present. They increasingly served as rallying points for a developing Nationalist cause, a part of which stressed both Catholic and Irish as almost indistinguishable, looking towards violent pagan epics to confirm this quintessentially Christian connection. The ironic quality of this process, moreover, was realised at the time. As George Russell (AE) put it at the beginning of the century,

Years ago, in the adventurous youth of his mind, Mr. O'Grady found the Gaelic tradition like a neglected antique dun with its door barred, and there was little or no egress. Listening, he heard from within the hum of an immense chivalry, and he opened the doors and the wild riders went forth to work their will. Now he would recall them. But it is in vain. [AE 1906:21, also cited in Williams 1983:312]

By the time of the Easter Rising in 1916, thanks in part to the sort of volumes that rest on Joe O'Brien's book shelves, Nationalist writers, artists, and political organizers could reasonably anticipate that an allusion to this literature would summon up a penumbra of meanings having to do with courage, loyalty, and heroic sacrifice 
in a population acquainted with at least the outlines of such stories. Hence, the cap badge of the Irish Volunteers, the paramilitary Nationalist organization, a part of which participated, fought and died in the Easter Rising, bore the initials FF, for Fianna Fáil [Soldiers of Destiny], from the Fianna, who surrounded the legendary Irish hero, Fionn mac Cumhaill, whose exploits were detailed in English in Lady Gregory's Gods and Fighting Men (Williams 1983:323). And, of course, the name of the party that De Valera established after the Civil War, Fianna Fáil maintains this connection.

Yet, in the end, the wild riders once again had other ideas. Seemingly content with something less than heroic absolutes, they disappointed the generation of Nationalists who came of age under them, just as they had the Unionist O'Grady a few decades before. Independence led to partition, and many of the relationships that were considered problematic by the cultural purists before the 1920s, were continued after the Civil War. The leaders of the new state, moreover, many of them like De Valera who had trained or laboured in state institutions before Independence, only tinkered with the bureaucratic apparatus that they inherited. Finally, the state that they constructed was bound to British markets to absorb both its largely agricultural produce and its surplus population off the land.

\section{Who does the Imagining?}

Clearly, those who were reading the "recovered" national mythology of Fionn and Cuchulain, who were at least listening to the fiery rhetoric of rebellion and the nostalgic rhetoric of reviving the authentically Irish from, say, the 1870 s on, must overlap demographically to a great extent with the same population that frustrated the cultural purists and nationalists in the twentieth century. The success of popularizing the ancient Gaelic sagas in the nineteenth century, and as importantly, the success of those Nationalists who appropriated these symbols while translating the hitherto lost folkloric wisdom of the Gaelic-speaking areas of the island in the twentieth century, was dependent upon a largely English-language and Irish Catholic readership.

By the time of the Free State, moreover, it was not at all clear how that part of this readership who were staffing Pearse's "murder machine," that is, Hyde's "anglicized" Irish, would fare. They might have found themselves in a conflicted symbolic situation that shares some formal similarities with being Coloured in post-Apartheid South Africa. They were at a disadvantage in the old colonial system because of their connection with a native Irish life that stood in need 
of a civilizing mandate. At the same time, they might have found the exchange value of their cultural currency in a new "nativist" regime questionable because of their relative success in the old order.

Thanks to at least two distinct waves of frustrated culture builders, however, by the 1920s, individuals like Joe O'Brien could now point to a very well developed national history and national literature. Indeed, Joe's lived sense of being located in a national tradition is now practically impossible for an outsider to refute. He is, for example, very fond of noting places in the Sligo-Leitrim area mentioned in Irish epics, particularly those associated with the story of Dermot and Grainne. ${ }^{8}$ Like most of the locals, his sense of the past is located in complex ways in his relationship to named spots on the landscape, a preeminently "traditional" Irish practice called dindsenechas (Coleman 1989, Hannan 1991, Mac Cana 1988, and Saris 1996). Nurses like him, for example, were the main vector by which this practice of naming and narrating places was imported into the asylum, and, thus, they formed a crucial element in the locality's domestication of an originally colonial institution (Saris 1996, 1999).

Joe's social practices as credentials of "localness" are also difficult to impeach. His loyalty and organizational efforts are granted to a political party that, in his words, "takes tradition seriously." Similarly, Mary O'Brien volunteers her time to an organization dedicated to maintaining "traditional" Irish handicrafts, even though she is aware, because of her interest in local history, that some of them, like linen work, were imported into the Kilronan area by "improving” Ascendancy landlords. Some of their children's musical talents may be the raw material for a future ethnomusicologist detailing the strength of "traditional" music in this area of Ireland. Understanding O'Brien's sense of an "Irish tradition" to be a sort of false consciousness, an "invention" to keep them from seeing where their truer interests lie, or even an invention by them to fool others, (e.g., Trevor-Roper 1984, Hobsbawm 1990, Gellner 1983), fundamentally evades the really interesting question: that is, how all the evident complexities around the terms "Irish" and "tradition" were and are negotiated and reproduced, both in individual lives as well as the historical consciousness of communities.

What seems evident is that the rural middle class in Ireland solved their specific tensions around "Irish Tradition" by, in effect, institutionalizing Hyde's clarion call, which itself became a source of moral authority. Taylor in a recent work has pointed out how certain Catholic spiritual periodicals aimed at a middle class readership both valorized and distanced "peasant piety," using it less as a model for strict emulation and more as an object of 
reflection and exhortation $(1992,1995)$. This seems to me to be a special case of a far more common phenomenon in the production of national traditions in Europe, that is the development of brokers standing between a source of tradition and its consumers (see also Bendix 1997, Frykman and Löfgren 1990, and Herzfeld 1987). Such "brokerage" presumes a consumer partly fallen away from an "authentic" tradition, which he or she still values, which, in its turn, is understood to be in a state of permanent fading. This relationship possesses several levels, from experts associated with the state, or other official organs, engaged in scholarly production in both history and folklore, to individuals at various localities who constitute an audience for such productions, as well as orienting aspects of their family and personal taste and style in terms of the supposed distinctiveness of this tradition.

Threats to this tradition, moreover, underscore its distinctiveness (something "other" is endangering it) as well as increasing its value. In Ireland, the treasure from the past never quite died, but was always under dire threat from the cold winds of any modern development. Still, this hot house flower, while failing to thrive in the outside world and only struggling to hold on to life in even the most protected of environments, robustly provided almost all the raw materiel for settling into, and decorating, Hyde's half-way house. The whitewashed cabin became admirable in itself while being left behind for other housing forms; a hard life of respectable rural poverty (enlivened by the wisdom of serene old men) could be idealized in the living room of a mental hospital nurse who would see very little of it, and certainly the Irish language could remain an object of great importance, even devotion of a sort, without it developing into the preferred vernacular for many.

The enduring success of the Gaelic Revival, then, exists not in rates of linguistic competence, or in the survival of family forms of economics, rather it lives in how the collection and/or manufacture of Celticana became an activity valued and debated for itself (compare to Handler 1986, 1988). From this point, even the most kitch object could potentially become a part of what Hroch (1993) correctly points out as what national consciousness is in fact conscious of - the shared historical experience of a group of human beings. It was also at this point that such material and symbolic items became available to coherent "common sense" schemas, potentially motivating political action (see also Darnton 1984: 974). In Ireland, this has meant, and continues to mean, debating the parameters of different pasts and their implied futures: was there an Irishness that struggled bloody but unbowed for 800 years of British rule (Corkery 1925, also Saul 1973) or was the Irish nation a nineteenth-century phenomenon, built on the back of feudal 
wreckage and an unsuccessful colonial state (O'Faolain 1938). Who were the culture bearers of this tradition - peasants and sharecroppers mired in the worst poverty in Europe, or patrician aristocrats assuming the partially reinvented airs of ancient Gaelic royalty? ${ }^{9}$ Are all bets off, now that "boom-town" Dublin is the most popular weekend holiday destination in Europe and supports the second highest number of gay saunas after Amsterdam? Is Irish culture now stronger or less authentic after the national and international success of River Dance? How such questions were, and are answered, or even if they were, and are legitimate, are the very stuff of cultural debates over the conflicted social reality that is "modern" Ireland.

\section{Conclusion}

As a preface to his excellent volume on the roots of the Anglo-Irish conflict, Oliver MacDonagh alludes to an apocryphal sentiment concerning the difference between English and Irish historical consciousness, "The English do not remember any history, the Irish forget none" (MacDonagh 1983:1). Substitute "large, dominant state" for "the English" and "small dominated nation" for "the Irish" and one probably has a widely applicable formula for the relationship between hegemonies, dominated populations, and the past. Of course, this formula, as it stands, is too simple. No human community is simply eidetic or amnesiac with respect to its past. Just as humans make history, but not just as they please, not in the time and the place of their own choosing, so too, are they constrained in how they remember, forget, and develop cultural practices around the past.

We can think of this process of remembering and forgetting as analogous to what Valeri (1972:37) has called in another context (with respect to remembered genealogies in Hawaiian dynastic struggles), the "lines of force" already present in society. In Ireland, at the end of the nineteenth century when the recovery work on an Irish tradition was in full flower, an important "line of force" was precisely this rural middle class of successful farmers, shopkeepers and state employees. In many parts of rural Ireland, they were the bridge between local worlds and broader structures, at once representing "modernizing" elements at their localities, while helping to "domesticate" those elements of the commodity economy and the nation-state with which they interacted (see Saris 1999).

As Lee (1989) and others have pointed out such families did well in post-Famine Ireland and did even better out of the Free State. It was the descendants of these individuals who inherited a colonial state structure more or less intact, and settled comfortably into it as the 
new elite. As part of this process, until recently, Mr. O'Brien and his family, and those in structurally similar positions, have done well in various cultural markets connected to this state, to use Bourdieu's terminology. By the middle part of this century, however, those who had monopolized this state structure began to use it in novel ways, opening up Irish markets (including cultural markets) to international capital and the products and profits of transnational corporations. At this point, the ideological inheritance of the state increasingly became a past to be transformed, if not overcome, in the interest of "development" (Brown 1985 and Gibbon 1988, 1996). Part of this development involved massive refigurings of Irish culture.

It is such changes that are finally moving the rural-oriented middle classes in Ireland into the category of "provincial bourgeoisie," predicted for them by Hyde more than a century ago, but not exactly for the reasons that he imagined. However things go, for example, Joe's cultural capital appears ready to plummet in this new world. Spurred on by the Celtic Tiger, Mr. O'Brien and his family now look pretty similar to (if not better off than) other Western European middle classes. For this reason, he is of little interest to cultural tourists seeking "traditional" Ireland (or, for that matter to many anthropologists interested in Irish culture). Ironically, tourists of the new world order eager to salvage authenticity in an age of instantaneous lifestyles will find more "culture" in a whitewashed cabin (although this might be owned by a German) than in a bungalow with obscure California-Spanish quotes; in a pony and trap, however recently reconstructed, rather than a late model Citroën. A heritage centre opened in the late 1990s dedicated to "interpreting" the cromlechs and stone circles around Kilronan interests such tourists more than the fauxGothic Catholic church in the town, finished in 1926, despite the important role that the latter still has in the life of the area. At the same time, Joe increasingly sits uncomfortably in a "middle" Ireland keen to be modern and European. His religiosity, in particular, is now understood as a sort of unfortunate survival by many social, government, and media elites in Dublin - a subject fit only for derision, satire, or exoticization (O'Toole 1996, Waters 1998, and Saris n.d.). Hyde's half-way house may finally be rendered ideologically untenable, not from pressure from below as was the dream of the Revival, but by international processes of capital mobility, mixing of populations, and ease of communication which are reconfiguring both the indexes and interpreters of the "authentic" Ireland. 


\section{Notes}

Part of this research was made possible by support from The American Council of Learned Societies and the Social Science Research Council Doctoral Research Program for Western Europe (1988-1990). I also owe thanks to the Charlotte W. Newcombe Foundation for dissertation write-up support (1991-1992). This essay has its roots in three separate conference papers. The first was a session, titled Ethnography and National Tradition in Europe, at the American Anthropological Association in 1992. The second was a session of the Annual Meeting of the American Conference of Irish Studies, Queens University, Belfast in 1995. The third was an invited lecture at the School of Social Studies, Science and Business (LSB) in Dublin in 1998. I would like to thank participants at these presentations and two anonymous reviewers of this paper. All mistakes and omissions, are, of course, entirely my own.

${ }^{1}$ Constance Markiewicz, the only female leader of the 1916 Rising, was spared by the English because of her gender. De Valera escaped the firing squads because of his American citizenship.

${ }_{2}$ The Irish Tourism Board.

${ }^{3}$ Around Kilronan, the connection between small farmers and lower level state employees is hardly news. In 1880 a bishop addressing a United Irishmen rally, in the aftermath of a shooting of a Land League demonstrator by the Royal Irish Constabulary, put this complex situation in the countryside succinctly, "They [the RIC] are all the sons of tenant farmers, and they do a good job with a bad situation nine times out of ten" (Sligo Champion 24 December 1880).

4 Anthropological work in Ireland, of course, predates Arensberg and Kimball's interest in "family and community" in the 1930s. In the middle of the nineteenth century, for example, self-styled amateur ethnologists produced something akin to national character studies, condemning the fecklessness of the Celtic "race" and expressing hope that the continuing infusion of Saxon blood and customs were bringing "progress" to Ireland (Ellis 1852). Towards the end of the century, C. R. Brown, an English doctor, conducted anthropometric work interspersed with some ethnographic observations in some sites in the west of the island (e.g., Haddon and Brown 1891). But, it was Arensberg and Kimball who established the "baseline" against which much subsequent American, English, even French, work in the west of Ireland would measure itself (e.g., Messenger 1969, 1971, Cresswell 1969, Brody 1973, Fox 1979, and Scheper-Hughes 1982).

${ }^{5} \mathrm{I}$ am in no way summarizing or even outlining the whole of recent Irish ethnography. The picture is more complicated in other parts of the island, and even work in "the West" is no longer very easy to characterise (e.g., Curtin and Wilson 1989). In the north, for example, Taylor $(1992,1995)$ works on a small community in Donegal, but is interested in this community over a long period of historical time and in relationship to the worldwide institution of the Catholic Church. Glassie (1984), on the other hand, presents a vision of an northern community more or less in line with the work described here for the west of Ireland. In still other works, the "community" has been seen as less a given of a holistic peasant society, and more a subject of serious research, focusing on how various unities and networks are mobilized both within and across the sectarian divide (e.g., Harris 1972). The south and southeast of Ireland has in recent years also been the target of much historically-informed anthropological scrutiny (see the various contributors to Silverman and Gulliver 1992, and Gulliver and Silverman 1995). Gulliver and Silverman (1995) and Silverman (1989), for example, argue that their emphasis on 
(predominantly) nineteenth-century social history is an important methodological innovation to the ethnography of Ireland (see also Wilson 1984 for overview). Finally, in the east of the island, Komito (1984), Wilson (1993), and Saris and Bartley (in press) have scrutinized urban and suburban settings.

${ }^{6}$ The left wing of the Independence movement, who saw in Ireland a history of class struggle, was probably the most frustrated, if least surprised, critic of this stratum. They soon found that the coalition that eventually exercised hegemony in the Free State and then the Republic, included this rural middle class and The Church as its leading elements (Inglis 1987).

7 I believe that Lee draws an unwarranted conclusion from this predominance or rural/small town leaders in the Irish nationalist movement, viz. that Ireland was relatively "integrated" and that center/periphery problems were, therefore, not acute.

${ }^{8}$ Through an unfortunate series of events, Dermot [Diarmuid], a warrior in the Fianna, wins the love of Grainne, the wife of Fionn. They elope and are chased around Ireland by the angry husband. In some versions of the story, Dermot dies tragically on the slopes of Ben Bulben in Sligo.

9 Recall the often over-looked fact that "Irish poverty" was an almost technical term in Continental social science literature at the end of the nineteenth century, a living example of the extremes of human endurance (see Engels (1966 (1870)).

\section{Bibliography}

AE (George Russell). 1906. Some Irish Essays. Dublin.

Anderson, Benedict. 1991. Imagined Communities: Reflections on the Origins and Spread of Nationalisms. New York: Verso.

Appadurai, Arjun. 1981. "The Past as a Scarce Resource.” Man 16: 201-219. Appadurai, Arjun. 1996. Modernity at Large : Cultural Dimensions of Globalization. Minneapolis, Minn.: University of Minnesota Press.

Arensberg, Conrad. 1937. The Irish Countryman. Cambridge, MA: Macmillan.

Arensberg, Conrad and Kimball, Solon. 1940. Family and Community in Ireland. Cambridge, MA: Harvard University Press.

Bendix, Regina. 1992. "National Sentiments in the Enactment and Discourse of Swiss Political Ritual.” American Ethnologist 19(4): 768-790.

Bendix, Regina. 1997. In Search of Authenticity: The Formation of Folklore Studies. Madison, WI: The University of Wisconsin Press.

Brody, Hugh. 1973. Inishkillane: Change and Decline in the West of Ireland. London: Jill Norman and Hobbhouse Ltd.

Brown, Terrence. 1985. Ireland: A Social and Cultural History, 1922-1985. London: Fontana Press.

Cairns, David and Shaun Richards. 1988. Writing Ireland: Colonialism, Nationalism, and Literature. Manchester: Manchester University Press.

Coleman, Steven. 1989. Fonn, Féile agus Filiocht: Poetry in an Irish Speaking District. Proposal for Thesis Research. The University of Chicago.

Coogan, Tim Pat. 1993. De Valera: Long Fellow, Long Shadow. London: Hutchinson.

Corkery, Daniel. 1925. The Hidden Ireland: A Study of Gaelic Munster in the Eighteenth Century. Cork: Lee Press.

Cresswell, Robert. 1969. Une Communauté Rurale de L'Irlande. Paris: Institute d' Ethnologie.

Curtin, C. and Wilson T. (eds.). 1989. Ireland From Below: Social Change and 
Local Communities. Galway: Galway University Press.

Darnton, Robert. 1984. The Great Cat Massacre And Other Episodes From French Cultural History. New York: Vintage Books.

Duffy, Sir Charles. 1894. The Revival of Irish Literature. London: T. Fischer.

Eagleton, Terrence, Jameson, Frederick, and Said, Edward. 1990. Nationalism, Colonialism, and Literature. Minneapolis: University of Minnesota Press.

Ellis, George. 1852. Irish Ethnology, Socially and Politically Considered; Embracing a General Outline of the Celtic and Saxon Races with Practical Inferences. Dublin: Hodges and Smith.

Engels, Fredrick. 1966 (1870). The Peasant War in Germany. New York: International Publishers.

Fernandez, James W. 1985. "Folklorists as Agents of Nationalism" New York Folklore. X(1-4): 135-147.

Fitzpatrick, David. 1977. Politics and Irish Life 1913-1921: Provincial Experience of War and Revolution. Dublin: Gill and Macmillan.

Flower, Robin. 1945. The Western Island or the Great Blasket. Oxford: Oxford University Press.

Foster, John W. 1987. Fictions of the Irish Literary Revival: A Changeling Art. Syracuse: Syracuse University Press.

Foster, Robert Fitzroy. 1989. Modern Ireland: 1600-1972. London: A. Lane.

Fox, Robin. 1978. The Tory Islanders: A People of the Celtic Fringe. Cambridge: Cambridge University Press.

Frykman, Jonas and Orvar Löfgren. 1990. Culture Builders: Historical Anthropology of Middle Class Life. New Brunswick: Rutgers University Press.

Gellner, Ernst. 1983. Nations and Nationalisms. Ithica: Cornell University Press.

Gibbon, Peter. 1973. "Arensberg and Kimball Revisited." Economy and Society. 2: 479-498.

Gibbons, Luke. 1988. "Coming out of Hibernation? The Myth of Modernity in Irish Culture." In Kearney, Richard (ed.) Across the Frontiers: Ireland in the 1990s. Dublin: Wolfhound Press.

Gibbons, Luke. 1996. Transformations in Irish Culture. Cork, Ireland: Cork University Press in association with Field Day.

Glassie, Henry. 1983. Passing the Time in Ballymenone: Culture and History of an Ulster Community. Philadelphia, PA: University of Pennsylvania Press.

Gregory, Lady Augusta. 1902. Cuchulain of Muirthemne. London and Dublin: John Murray.

Gregory, Lady Augusta. 1904. Gods and Fighting Men. London and Dublin: John Murray.

Gregory, Lady Augusta. 1920. Visions and Beliefs in the West of Ireland. 2 Vols. London: G.P. Puntnam's Sons.

Gulliver, P.H. and Marilyn Silverman. 1995. Merchants and Shopkeepers: A Historical Anthropology of an Irish Market Town, 1200-1991. Toronto: University of Toronto Press.

Handler, Richard. 1986 “Authenticity.” Anthropology Today. 2(1): 2-4.

Handler, Richard. 1988. Nationalism and the Politics of Culture in Guebec. Madison: University of Wisconsin Press

Hannan, R. 1991. "An Ball Uaigneach Seo: Attachment to Place in Gaelic Literature." Éire-Ireland XXVI: 2: 19-31.

Harris, Rosemary. 1972. Prejudice and Tolerance in Ulster: A Study of "Neighbours" and "Strangers" in a Border Community. Manchester: Manchester University Press. 
Herder, Johan von (trans. T. Churchill). 1803. Outlines of a Philosophy of the History of Man. London.

Herzfeld, Michael. 1982. Ours Once More: Folklore, Ideology, and The Making of Modern Greece. Austin: University of Texas Press.

Herzfeld, Michael. 1987. Anthropology Through the Looking Glass: Critical Ethnographies in the Margins of Europe. Cambridge: Cambridge University Press.

Higgins, Michael D. 1985. “Liam O’Flaherty and Pedar O’Donnell - Images of Rural Community." The Crane Bag. 9(1): 41-48.

Hobsbawm, Eric. 1990. Nations and Nationalism Since 1780. Cambridge: Cambridge University Press.

Hroch, Miroslav. 1993. "From National Movement to the Fully-formed Nation: The Nation-building Process in Europe" New Left Review. 198 (March/April): 3-20.

Hull, Eleanor. 1909. Cuchulain, The Hound of Ulster. London.

Hyde, Douglas. 1894. "The Necessity for De-Anglicizing Ireland." In Duffy, Sir Charles, The Revival of Irish Literature.

Inglis, Thomas. 1987. Moral Monopoly. Dublin: Gill and McMillan.

Inglis, Thomas. 1991. "The Struggle for Control of the Irish Body: State, Church, and Society in Nineteenth-Century Ireland" in Wolf, E. (ed.) Religious Regimes and State-Formation. Albany: State University of New York Press.

Irish Press. 1943. 18 March.

Kiely, Benedict. 1989. Yeats' Ireland: An Illustrated Anthology. London: Aurum Press.

Komito, Lee. 1984. "Irish Clientelism: A Reappraisal." Economic and Social Review. 15(3): 173-94.

Larkin, Emmet. 1984. The Historical Dimensions of Irish Catholocism. New York: Catholic University Press.

Lee, Joseph. 1989. Ireland 1912-1985: Politics and Society. Cambridge: Cambridge University Press.

Linke, Uli. 1990. "Folklore, Anthropology, and the Government of Social Life." Comparative Studies in Society and History 32: 117-148.

Lyons, F.S.L. 1979. Culture and Anarchy in Ireland, 1890-1939. Oxford: Oxford University Press.

Lyons, F.S.L. 1983. "Yeats and the Anglo-Irish Twilight." In MacDonagh, O., Mandle, W.F., and Travers, P. (eds.). Irish Culture and Nationalism, 17501950. Canberra: Humanities Research Centre.

MacCana, P. 1988. "Placenames and Mythology in Irish Tradition: Places, Pilgrimages and Things." In MacLennan, G. Proceedings of the First North American Congress of Celtic Studies. Ottawa.

MacDonagh, Oliver. 1983. States of Mind: A Study of the Anglo-Irish Conflict, 1780-1970. London: George Allen \& Unwin.

Mandle, W.F. 1983. "The Gaelic Athletic Association and Popular Culture, 1884-1924).” In MacDonagh, O., Mandle, W.F., and Travers, P. (eds.) Irish Culture and Nationalism, 1750-1950. Canberra: Humanities Research Centre.

Messenger, John. 1969. Inis Beag: Isle of Ireland. New York: Holt, Rinehart, and Winston.

Messenger, John. 1971. "Sex and Repression in an Irish Folk Community." In Marshall, D. and Suggs, R. (eds.) Human Sexual Behavior. New York: Basic Books.

Mosse, George. 1985. Nationalism and Sexuality. Madison, WI: The University of Wisconsin Press.

Moynihan, Maurice (ed.). 1980. Speeches and Statements by Eamonn de 
Valera. Dublin: Gill and MacMillan.

O'Faolain, Sean. 1980 (1938). King of the Beggars. Swords, Dublin: Poolbeg Press.

O'Grady, Standish. 1878. History of Ireland. Volume I: The Heroic Period. Dublin: E. Ponsonby.

O'Sullivan, Sean (ed.). 1966. Folktales of Ireland. Chicago: University of Chicago Press.

O’Toole, Fintan. 1985. "Going West: The Country versus the City in Irish Writing." The Crane Bag. 9: 2 111-116.

O’Toole, Fintan. 1996. Ex-Isle of Erin: Images of Global Ireland. Dublin: New Island Books.

O'Toole, Fintan. 1998. The Lie of the Land: Irish Identities. Dublin: New Books.

Peace, Adrian. 1989. "From Arcadia to Anomie.” Critique of Anthropology.89111.

Pearse, Padraig H. 1986. The Murder Machine And Other Essays. Dublin: Mercier Press.

Popot, R. 1979. Mythes et Nationalisme: L'exemple Irlandais. Gaeliana: Université de Caen.

Rafroidi, P. 1983. "Imagination and Revolution: The Cuchulain Myth." In MacDonagh, O., Mandle, W.F., and Travers, P. (eds.) Irish Culture and Nationalism, 1750-1950. Canberra: Humanities Research Centre.

Saris, A. Jamie. 1994. The Proper Place For Lunatics: Asylum, Person, and History in a Rural Irish Community. Ph.D. Thesis. The University of Chicago.

Saris, A. Jamie. 1996. "Mad Kings, Proper Houses, and an Asylum in Rural Ireland." American Anthropologist. 98(3): 539-554.

Saris, A. Jamie. 1997. "The Asylum in Ireland: A Brief Institutional History and Some Local Effects." In Cleary, Anne and Margaret P. Tracy (eds.) The Sociology of Health and Illness in Ireland. Dublin: University College Dublin Press.

Saris, A. Jamie. 1999. "Producing Persons and Developing Institutions in Rural Ireland” American Ethnologist. 26(3): 1-21.

Saris, A. Jamie. n.d. "Debatably Irish: Stereotypes of Irrationality and the Politics of Identity in the Work of the Irish Times Columnist John Waters."

Saris, A. Jamie and Brendan Bartley et al. In press. "Horses 'in the Balance of Relativity': The Culture of Protest In West Dublin.” In Peillon, Michel and Eamonn Slater (eds.) Irish Sociological Chronicles, Volume II. Dublin: Institute for Public Administration.

Saul, G.B. 1973. Daniel Corkery. Lewisberg: Bucknell University Press.

Scheper-Hughes, Nancy. 1982. Saints, Scholars, and Schizophrenics. Berkeley: University of California Press.

Sheehy, Michael. 1968. Is Ireland Dying? London: Hollis and Carter.

Silverman, Marilyn. 1989. "A Labouring Man's Daughter." In Curtin, C. and Wilson T. (eds.). Ireland From Below: Social Change and Local Communities. Galway: Galway University Press.

Silverman, Marilyn and Gulliver, P.H. (eds.). 1992. Approaching the Past: Historical Anthropology Through Irish Case Studies. New York: Columbia University Press.

Sweeney, P. 1998. The Celtic Tiger: Ireland's Economic Miracle Explained. Dublin: Oak Tree Press.

Taylor, Lawrence. 1992. "Languages of Belief: Nineteenth-Century Religious Practices in Southwest Donegal." In Silverman, M. and Gulliver, P. (eds.) Approaching the Past: Historical Anthropology Through Irish Case Studies. New York: Columbia University Press. 
Taylor, Lawrence. 1995. Occasions of Faith: An Anthropology of Irish Catholics. Dublin: Lilliput Press.

Trevor-Roper, Hugh. 1984. "The Invention of Tradition: The Highland Tradition of Scotland." In Hobsbawm, Eric and Ranger, Terence (eds.) The Invention of Tradition. Cambridge: Cambridge University Press.

Valeri, Valerio. 1972. "Le Fonctionnement du système des rangs à Hawai." L'Homme. 12: 29-66.

Waters, John. 1998. An Intelligent Person's Guide to Modern Ireland. London: Duckworth.

Williams, Martin. 1983. "Ancient Mythology and Revolutionary Ideology in Ireland, 1878-1916." The Historical Journal. 26(2): 307-328.

Wilson, Thomas. 1984. "From Clare to the Common Market: Perspectives in Irish Ethnography." Anthropological Quarterly. Vol 57, No. 1: 1-15.

Wilson, Thomas. 1993. "What Price Europe? Liminality, The EC, and the Irish Border." Paper Presented at the 92nd Annual Meeting, Washington, DC.

Yeats, William Butler. 1951. Irish Folk Stories and Fairy Tales. New York: Grossett. 